\title{
PENGGUNAAN TEKNOLOGI REAKTOR MICROBIAL FUEL CELLS (MFCs) DALAM PENGOLAHAN LIMBAH CAIR INDUSTRI TAHU UNTUK MENGHASILKAN ENERGI LISTRIK
}

\author{
Purwono $^{1}$, Hermawan $^{2}$, Hadiyanto ${ }^{3}$ \\ ${ }^{1}$ MahasiswaMagister Ilmu Lingkungan UNDIP, Semarang \\ ${ }^{2,3}$ Dosen Program Pascasarjana llmu Lingkungan UNDIP, Semarang \\ JI. H. Prof. Sudarto, SH, Tembalang, Semarang \\ E-mail: pur_121@yahoo.com
}

\begin{abstract}
ABSTRAK
Microbial Fuel Cells (MFCs) adalah bioreaktor yang mengubah energi kimia dari senyawa organik menjadi energi listrik melalui reaksi katalitik mikroorganisme dalam kondisi anaerob. Tujuan dari penelitian ini adalah mengetahui pengaruh variasi media terlekat (attached growth media) dan variasi konsentrasi $C O D$ awal terhadap efisiensi penyisihan konsentrasi COD dan energi listrik yang dihasilkan. Reaktor MFCs didesain dalam bentuk dual-chamber yang dihubungkan menggunakan jembatan garam. Kerikil dan bioball digunakan sebagi variasi media lekat pada kompartemen anoda dan konsentrasi limbah awal divariasikan dari 0\%, 25\%, 50\%, dan 100\% dari konsentrasi COD limbah cair industri tahu asli dengan cara melakukan pengenceran.Hasil penelitian menunjukkan bahwa media lekat kerikil dengan konsentrasi 50\% menghasilkan arus listrik rata-rata tertinggi 7,25 $\mu \mathrm{A}$ dan energi listrik sebesar 179,54 mWh. Voltase dan enegi listrik pada kedua variasi tersebut semakin hari semakin menurun. Variasi konsentrasi 25\%, 50\%, dan 100\% menghasilkan penurunan nilai effisiensi penyisihan COD masing-masing 41,41\%; 39,90\% dan 18,26\%.Pada variasi $100 \%$ menghasilkan energi listrik lebih rendah dari pada 50\%. Kemungkinan hal ini karena adanya senyawa sulfida yang berperan sebagai akseptor elektron. Pembentukan senyawa sulfida ditandai dengan terbentuknya warna hitam pada substrat. Efisiensi coulombic $(\varepsilon C)$ akibat perbedaan media lekat dan variasi konsentrasi berada pada kisaran 0,001-0,035\%. Rendahnya $\varepsilon C$ kemungkinan karena adanya produkproduk fermentasi dan biofilm pada elektroda anoda yang menghambat transfer elektron menuju elektroda anoda seperti biomassa, bahan organik terlarut, gas $\mathrm{H}_{2}$ dan gas $\mathrm{CH}_{4}$.
\end{abstract}

Kata kunci: Microbial Fuel Cells (MFCs), media lekat, variasi konsentrasi

\section{PENDAHULUAN}

Industri tahu telah berkembang secara turun temurun di berbagai wilayah Indonesia pada skala mikro dengan proses produksi secara tradisional. Pembuatan tahu selain menghasilkan produk utama berupa tahu, juga menghasilkan ampas tahu dan limbah cair (Said dan Wahjono, 1999). Penelitian tentang pemanfaatan limbah cair pembuatan tahu telah dilakukan Limbah cair industri tahu dapat dimanfaatkan untuk menghasilkan biogas (Wagiman dan Suryandono, 2006; Widarti, dkk., 2012).

Perkembanganllteknologi pengolahan limbah cair industri tahu terus ditemukan. Teknologi Microbial Fuel Cells (MFCs) merupakan salah satu metode yang digunakan untuk mengolah limbah cair yang mengandung bahan organik (Habermann dan Pommer,1991). Microbial Fuel Cells (MFCs) adalah bioreaktor yang mengubah energi kimia dari senyawa organikmenjadi energi listrik melalui reaksi katalitik mikroorganisme dalam kondisi anaerob
(Logan , 2007). Energi listrik yang dihasilkan pada proses pengolahan limbah menggunakan teknologi MFCs memiliki potensi sebagai pemasok sumber energi. Penggunaan air limbah dalam sistem MFCs mempunyai keuntungan tersendiri yaitu polutan dalam limbah cair dapat menjadi sumber karbon untuk menghasilkan energi listrik (Li dkk, 2011). Menurut Franks and Nevin. (2010), terbatasnya aplikasi MFCs dalam skala luas semata-mata karena energi listrik yang dihasilkan masih rendah. Walaupun demikian, teknologi MFCs merupakan teknologi yang menjanjikan untuk menghasilkan energi listrik dari bahan organik dan limbah.

Limbah domestik, limbah cair industri makanan, dan limbah cair babi merupakan sumber karbon yang besar karena mengandung bahan organik (Liudkk, 2004; Logan, 2005; Min dkk, 2005; Zhou dkk, 2011). Konsentrasi Chemical Oxygen Demand (COD) limbah dapat diturunkan sampai 80\% (Liudkk, 2004; Min dkk, 2005). Limbah tahu memiliki konsentrasi COD pada kisaran 7.500-14.000 mg/1 (Kaswinarni, 
2007). Konsentrasi COD limbah semakin besar, maka proses degradasi akan semakin lama. Elektron $\left(\mathrm{e}^{-}\right)$dan proton $\left(\mathrm{H}^{+}\right)$yang dihasilkan pada kompartemen anoda semakin meningkat (Haslett,2012). Berdasarkan penyataan ini diharapkan tegangan listrik yang dihasilkan akan semakin besar.

Pengolahan limbah cair menggunakan biofilter anaerob merupakan teknologi pengolahan yang murah, mudah operasinya serta hemat energi. Konsep teknologi pengolahan dengan biofilter anaerob merupakan suatu istilah dari reaktor yang dikembangkan dengan prinsip mikroba tumbuh dan berkembang menempel pada suatu media filter (media terlekat) dan membentuk biofilm (attached growth). Biofilter dapat digunakan untuk air limbah dengan beban COD yang cukup besar dan dapat menghilangkan padatan tersuspensi (SS) dengan baik (Wijeyekoondkk, 2004)

Berdasarkan hal tersebut maka perlu dilakukan penelitian tentang pengaruh media terlekat dalam reaktor MFCs terhadap konsentrasi COD dan besarnya energi listrik yang dihasilkan. Penelitian ini akan dilakukan pengolahan limbah cair industri tahu dengan variasi media terlekat dan vaariasi konsentrasi COD dari limbah yang sama. Efisiensi penyisihan konsentrasi COD dan energi listrik yang dihasilkan dari masing-masing proses akan dianalisa secara intensif.

\section{METODOLOGI PENELITIAN}

Tabel1. Rincian reaktor penelitian dalam kompartemen anoda

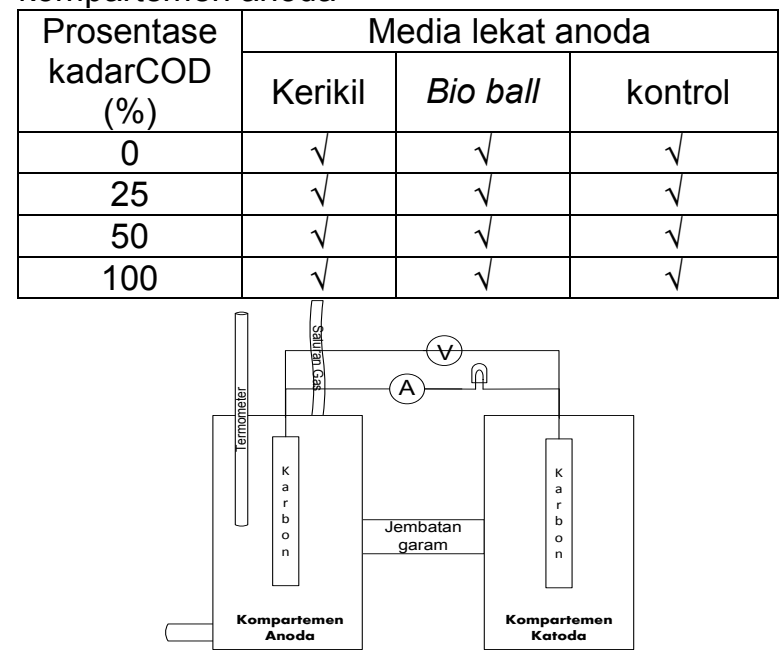

Gambar1.Desain Reaktor MFCs menggunakan media terlekat
Tabel 2. Pelaksanaan penelitian dan waktu pengambilan sampel

\begin{tabular}{|c|l|l|l|}
\hline $\begin{array}{c}\mathrm{N} \\
0\end{array}$ & Parameter & \multicolumn{1}{|c|}{$\begin{array}{c}\text { Frekuensi } \\
\text { Pengukuran }\end{array}$} & \multicolumn{1}{|c|}{ Metode } \\
\hline 1 & Arus listrik & $\begin{array}{l}\text { Setiap 1 jam } \\
\text { sekali }\end{array}$ & Multi-meter \\
\hline 2 & Tegangan & $\begin{array}{l}\text { Setiap 1 jam } \\
\text { sekali }\end{array}$ & Multi-meter \\
\hline 3 & $\mathrm{COD}$ & 2 hari sekali & $\begin{array}{l}\text { Spektrofotome } \\
\text { tri }\end{array}$ \\
\hline 4 & $\mathrm{pH}$ & Setiap hari & potensiometri \\
\hline
\end{tabular}

\section{A. Perhitungan Efisiensi Penyisihan}

Efisiensinya dapat dihitung menggunakan persamaan berikut :

$\varepsilon_{\text {COD }}=\frac{C_{\text {in }}-C_{\text {out }}}{C_{\text {in }}} \times 100 \%$

dimana :

$\varepsilon \mathrm{COD}=$ Prosentase penyisihan konsentrasi COD (\%)

$\mathrm{C}_{\text {in }} \quad=$ Konsentrasi COD pada titik

masuk (inlet) (mg/l)

$\mathrm{C}_{\text {out }} \quad=$ Konsentrasi COD pada titik keluar (outlet) (mg/l)

\section{B. Perhitungan energi listrik}

Energi listrik yang dihasilkan dirumuskan sebagai berikut

$\mathrm{W}=\mathrm{I} . \mathrm{V} \cdot \mathrm{t}$

dimana:

$$
\begin{array}{ll}
\mathrm{W} & =\text { energi listrik (watt) } \\
\mathrm{I} & =\text { kuat arus (amper) } \\
\mathrm{V} & =\text { tegangan (Volt) } \\
\mathrm{T} & =\text { waktu (jam) }
\end{array}
$$

\section{Efisiensi Coulombic $(\varepsilon \mathrm{C})$}

$$
\varepsilon_{C b}=\frac{M \int_{0}^{t D} l d t}{F b V_{A n} \Delta C O D} .
$$

\section{Dimana:}

$$
\begin{array}{ll}
\varepsilon_{\mathrm{Cb}} & =\text { Efisiensi Coulombic } \\
\mathrm{M} & =\text { Berat molekul Oksigen }(32 \mathrm{~g} / \mathrm{mol}) \\
\mathrm{F} & =\text { Konstanta Faraday }(96500) \\
\mathrm{b} & =\text { Jumlah pertukaran elektron per } \\
& \text { mol oksigen }(4) \\
\mathrm{V}_{\mathrm{an}} & =\text { Volume cairan dalam } \\
& \text { kompatemen anoda }(\mathrm{L}) \\
\Delta \mathrm{COD} & =\text { perubahan konsentrasi COD } \\
& \text { dalam periode waktu tertentu }
\end{array}
$$

\section{HASIL DAN PEMBAHASAN}

\section{Karakteristik Air Limbah Tahu}

Berdasarkan hasil analisis pendahuluan yang tercantum pada Tabel 3. dapat diketahui rasio BOD/COD limbah sebesar 0,491 . Nilai ini menunjukkan limbah cair tahu bersifat biodegradable (Alaerts dan Santika, 1984). 
Tabel 3.Hasil Uji Karakteristik Awal Air Limbah Tahu dengan prosentase konsentrasi COD 0\%, $25 \%, 50 \%$, dan $100 \%$ dari konsentrasi limbah asli

\begin{tabular}{|c|c|c|c|c|}
\hline \multirow{2}{*}{ No } & \multirow{2}{*}{$\begin{array}{c}\text { Kode } \\
\text { sampel }\end{array}$} & $\begin{array}{c}\text { COD } \\
(\mathrm{mg} / \mathrm{l})\end{array}$ & $\mathrm{pH}$ & $\begin{array}{c}\text { Suhu } \\
\left({ }^{\circ} \mathrm{C}\right)\end{array}$ \\
\hline 1 & $0 \%$ & 7,11 & 6,77 & 28 \\
\hline 2 & $25 \%$ & 884,62 & 4 & 34 \\
\hline 3 & $50 \%$ & $4.177,48$ & 3,81 & 36 \\
\hline 4 & $100 \%$ & $8.846,24$ & 3,74 & 43 \\
\hline
\end{tabular}

\section{Reaksi Kimia di Kompartemen Katoda}

Proton dan elektron yang berasal dari anoda digunakan untuk mereduksi $\mathrm{Mn}^{7+}$ menjadi $\mathrm{Mn}^{4+}$ (Guerrero-Rangel dkk, 2010).Reaksi yang terjadi pada kompartemen katoda sebagai berikut :

$\begin{aligned} & \mathrm{MnO}_{2}^{-}+4 \mathrm{H}^{+}+3 \mathrm{e}^{-} \\ & \mathrm{O}^{-}+\mathrm{H}^{+}\end{aligned} \mathrm{MnO}_{2}+2 \mathrm{H}_{2} \mathrm{O}$

Hasil hidrolisis bahan organik kompleks di gunakan sebagai sumber energi untuk tahap berikutnya. Gula sederhana sebagai molekul biodegradable terdegradasi seperti persamaan berikut:

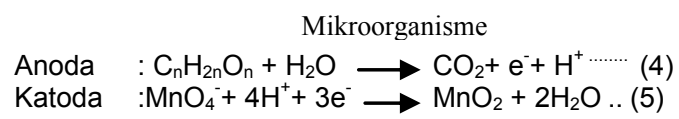

Pada tahap diatas tampak bahwa elektron sudah bisa dihasilkan dari dekomposisi senyawa sederhana. Menurut Lovley (2008), asam asetat dan asam sederhana lainnya merupakan sumber elektron utama untuk menghasilkan arus. Asam asetat akan terdegradasi seperti yang ditunjukkan berikut:

\section{Mikroorganisme}

Anoda $: \mathrm{CH}_{3} \mathrm{COOH}+2 \mathrm{H}_{2} \mathrm{O} \rightarrow \mathrm{CO}_{2}+8 \mathrm{e}^{-}+8 \mathrm{H}^{+}$

\section{Efisiensi penyisihan konsentrasi COD pada reaktor MFCs}

Pada akhir penelitian selama 13 hari penyisihan COD stabil $( \pm 10 \%)$, pengolahan limbah dengan variasi media lekat kerikil menunjukan efisiensi yang paling tinggi dibanding dengan media lekat bioball, baik pengenceran $0 \%, 25 \%, 50 \%$, maupun $100 \%$. Perbedaan efisiensi penyisihan COD kemungkinan akibat perbedaan kekasaran media lekat antara kerikil dan bioball. Kerikil memiliki permukaan yang lebih kasar daripada permukaan bioball. Kekasaran mewakili jumlah dan ukuran celah-celah dimana mikroorganisme dapat mengawali pertumbuhan tanpa gangguan gaya geser aliran air. Pada tahapan awal, sifat dari media lekat memainkan peran terpenting. Kekasaran media lekat mempromosikan kolonisasi bakteri. Hipotesanya adalah rekahan dalam permukaan kasar dapat memproteksi pertumbuhan biofilm selama periode awal dari gaya geser akibat hidrodinamik cairan. Hal ini memungkinkan perkembangan biofilm tahap berikutnya.

\section{Kuat Arus listrik pada variasi media lekat}

Menurut Lee dkk (2008), konsentrasi COD substrat dalam MFCs yang mengandung bahan organik kompleks ditetapkan dalam kesetimbangan massa konsentrasi COD dalam MFCs sebagai berikut:

$$
\begin{aligned}
& \mathrm{COD}_{\text {awal }}=\mathrm{COD} \text { arus }+\mathrm{COD}_{\text {bio sus }}+\mathrm{COD}_{\text {bio lekat }}+ \\
& \text { COD } \text { Gas }+\mathrm{COD}_{\text {akhir }}+\mathrm{COD}_{\text {lainnya }} \\
& \mathrm{COD}_{\text {awal }}=\text { konsentrasi } \mathrm{COD} \text { awal pada } \\
& \text { kompartemen anoda } \\
& \mathrm{COD}_{\text {arus }} \quad=\text { konsentrasi } \mathrm{COD} \text { yang } \\
& \text { diubah menjadi arus selama } \\
& \text { periode waktu tertentu } \\
& \mathrm{COD} \text { bio sus }=\text { konsentrasi } \mathrm{COD} \text { untuk } \\
& \text { membentuk biomassa } \\
& \text { tersuspensi selama } \\
& \text { periode waktu tertentu } \\
& \mathrm{COD}_{\text {biolekat }}=\text { konsentrasi COD untuk } \\
& \text { pembentuk biomassa terlekat } \\
& \text { padakompartemen anoda } \\
& \mathrm{COD} \text { Gas = konsentrasi COD untuk } \\
& \text { membentuk akumulasi gas } \\
& \mathrm{CH}_{4} \text { dan } \mathrm{H}_{2} \\
& \mathrm{COD}_{\text {akhir }}=\mathrm{COD} \text { terlarut sebagai hasil } \\
& \text { pengolahan } \\
& \mathrm{COD}_{\text {lainnya }}=\text { konsentrasi } \mathrm{COD} \text { yang tidak } \\
& \text { berhubungan dengan arus } \\
& \text { listrik }
\end{aligned}
$$

Hasil penelitian menunjukkan substrat dengan media lekat kerikil menghasilkan arus listrik rata-rata sebesar $7,25 \mu \mathrm{A}$ pada variasi limbah cair tahu $50 \%$ dari konsentrasi limbah asli. Arus listrik dengan media lekat bioball menghasilkan arus sebesar 5,48 $\mu \mathrm{A}$ pada variasi limbah cair tahu $50 \%$. Arus listrik dengan variasi media lekat kerikil menghasilkan arus lebih banyak dibandingkan dengan media lekat bioball. Berdasarkan hasil uji Multiple Comparisons, media lekat kerikil dan media lekat bioball menunjukkan perbedaan signifikan yang di tunjukkan dari nilai signifikansi sebesar 0,000. Hal ini sebanding dengan nilai efisiensi penyisihan COD pada media lekat kerikil mencapai $39,90 \%$. Perbedaan ini kemungkinan karena adanya perbedaan efisiensi penyisihan COD dimana media lekat kerikil menghasilkan efisiensi lebih besar dari padabioball. 


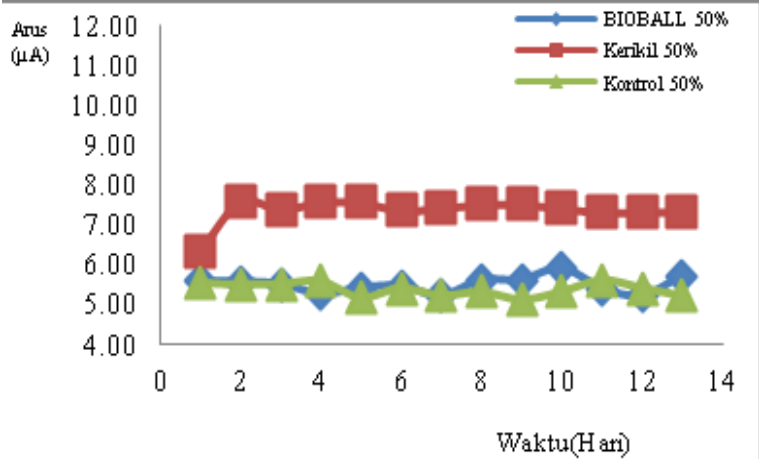

Gambar 2. Kurva Arus listrik dengan media lekat bioball, kerikil, dan tanpa media lekatprosentase $50 \%$ dari limbah asli

Efisiensi coulombic $(\varepsilon C)$ tertinggi mencapai $0,014 \%$ pada substrat dengan variasi konsentrasi $25 \%$. Dalam hal ini tampak bahwa elektron yang dihasilkan dari proses pengolahan limbah tidak sepenuhnya ditransfer manjadi arus listrik melalui rangkaian eksternal. Kondisi ideal terjadi ketika Efisiensi Coulombic $(\varepsilon \mathrm{C})$ mencapai nilai $100 \%$ artinya semua elektron yang dihasilkan akan diubah menjadi arus listrik (Logan, 2007). Efisiensi Coulombic ini termasuk dalam kategori rendah apabila dibandingkan dengan substrat asetat dengan rentang nilai $\varepsilon C$ sebesar 65\%-84\% (Min dan Logan, 2004; Liu dkk, 2004; Rabaey dan Verstraete, 2005), sedangkan substrat limbah yang memiliki bahan organik kompleks menghasilkan $\varepsilon$ C $8 \%$.

RendahnyacC kemungkinan disebabkan oleh aktifitas pembentukan biofilm pada permukaan elektroda anoda. Pada proses pengolahan awal, energi yang dihasilkan dari metabolisme bahan organik (dinyatakan sebagai COD awal) sebagian besar digunakan untuk membentuk biofilm. Sel-sel teradsorpsi dipermukaan media kemudian tumbuh, berkembangbiak dan menghasilkan Extracellular Polymeric Substances (EPS) untuk membentuk biofilm. Elektroda karbon pada kompartemen anoda MFCs juga berperan menjadi media lekat bagi mikroorganisme untuk membentuk biofilm. Selain sel bakteri hidup dan sel bakteri yang mati dapat membentuk lapisan pada permukaan anoda semakin bertambah. Terbentuknya biofilm ini dapat mengakibatkan peningkatan hambatan dalam di anoda (Kim dkk, 2003). Apabila permukaan elektroda ini sudah dipenuhi oleh biofilm, jumlah elektron yang dapat ditransfer ke elektroda akan sedikit sehingga terjadi penurunan arus listrik.

Menurut Zhang (2012), kekasaran permukaan elektroda/media lekat bisa mempengaruhi keanekaragaman jenis bakteri pembentuk biofilm yang mempengaruhi aktivitas biofilm dan transfer massa dalam permukaan media lekat. Permukaan media lekat yang kasar memungkinkan pelekatan bakteri, kolonosasi bakteri, ikatan antar bakteri lebih kuat dan jenis bakterinya bermacam-macam (heterogen). Sedangkan permukaan media lekat yang lebih halus cenderung terbentuk biofilm yang cenderung homogen (Kawai dkk, 2000; Quirynen dan Bollen, 1995; Tang dkk, 2007).

Selain adanya pengaruh biofilm, menurut Lovley (2008); Jung (2007), dan Holmes.(2007), substrat bahan organik kompleks juga berpengaruh terhadap arus listrik. Menurut Min dan Logan (2004); Rabaeydan Verstraete (2005), asam asetat dan asam sederhana lainnya merupakan sumber elektron utama untuk menghasilkan arus listrik. Apabila merujuk pada komposisi limbah cair industri tahu, komponen utama limbah terdiri dari protein, karbohidrat, dan lemak. Kompartemen anoda dengan substrat glukosa sebagai bahan yang dapat terfementasi terdeteksi gas $\mathrm{CH}_{4}$ dan asam-asam organik seperti asam pirufat, asam format propionat, butirat. Senyawa tersebut merupakan produk proses fermentasi. Produk fermentasi bahan organik kompleks limbah cair menjadi penghambat elektron yaitu biomassa, bahan organik terlarut, gas $\mathrm{H}_{2}$ dan gas $\mathrm{CH}_{4}$ (Min dkk, 2005).

Biomassa merupakan penghambat elektron yang paling besar dalam menghantarkan arus listrik dalam rekator MFCs (Lovley. 2008). Menurut Metcalf dan Eddy(1991), pada pengolahan limbah secara anaerob, biomassa terlekat lebih banyak dari pada biomassa tersuspensi. Kompartemen anoda mengandung media lekat berupa kerikil dan bioballyang menjadi tempat terbentuknya biofilm. Selain kerikil dan bioball, elektroda karbon juga berfungsi sebagai media lekat biofilm.

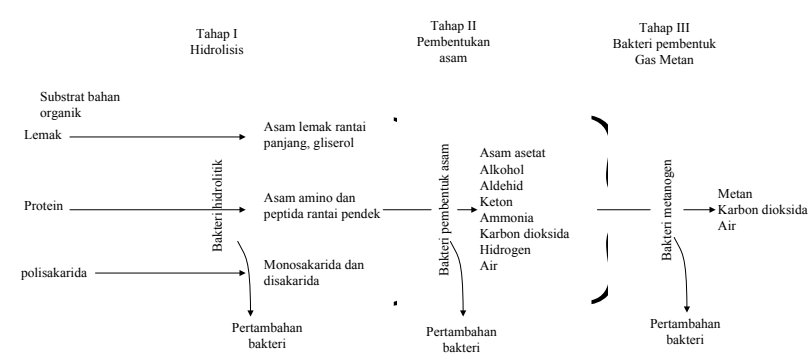

Gambar 3. Rangkaian tahap pembentukan biomassa pada pengolahan sistem anaerob Sumber: Madigan dkk, 2011

\section{Tegangan listrik pada variasi media lekat}

Variasi media lekat pada konsentrasi $25 \%$ limbah asli menghasilkan tegangan antara 713,38-725,67 $\mathrm{mV}$ pada awal penelitian. Tegangan semakin lama semakim menurun sampai pada kisaran 592-670 mV. Hal ini juga terjadi pada MFCs dengan variasi konsentrasi 
$50 \%$ dan $100 \%$ masing-masing antara 118,71 $1200,83 \mathrm{mV}$ menjadi 559-1032 mV dan 1137$1222,96 \mathrm{mV}$ turun menjadi 1013-1070 mV. Gambar 5 sampai Gambar 6 menunjukkan tegangan yang dihasilkan selama penelitian.

Bahan organik kompleks kemungkinan besar tidak secara langsung digunakan oleh mikroorganisme untuk menghasilkan arus, melainkan harus diubah terlebih dahulu menjadi senyawa yang lebih sederhana melalu proses fermentasi. Fermenter bahan organik harus tumbuh dari ukuran/ukuran yang sangat kecil dalam anoda. Hal ini dibuktikan rendahnya arus yang dihasilkan selama 13 hari mengindikasikan rendahnya katalis transfer elektron ke anoda. Kemungkinan pertumbuhan dan akumulasi fermenter (biomassa) cenderung memperlebar kompetisi dengan mikroorganisme yang terdapat disekitar anoda untuk mentransfer elektron.

Biomassa merupakan penghambat elektron yang paling besar dalam menghantarkan arus listrik dalam reaktor MFCs (Lovley, 2008). Adanya biofilm memungkinkan terhambatnya transfer massa, seperti substrat melalui lapisan EPS dapat menghambat pertumbuhan mikrobiologi di dasar biofilm. Padahal substrat itu sendiri merupakan sumber donor elektron. Hal ini menyebabkan potensial anoda menjadi lebih positif dan potensial sel totalnya semakin hari semakin menurun (Bard.1985).

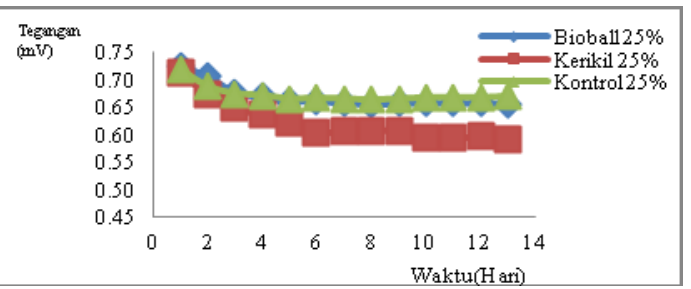

Gambar 4. Kurva Tegangan (mV) dengan media lekat bioball, kerikil, dan tanpa media lekatprosentase $25 \%$ dari limbah asli

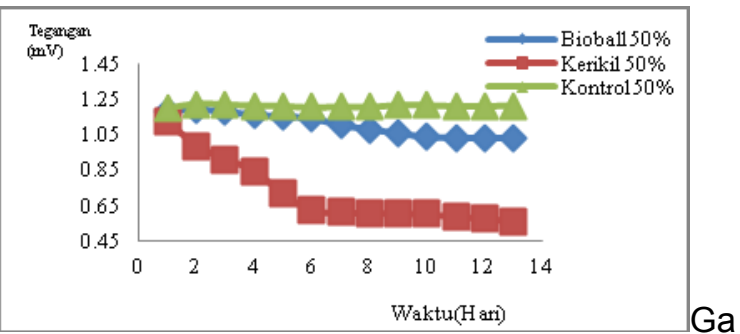

mbar 5. Kurva Tegangan $(\mathrm{mV})$ dengan media lekatbioball, kerikil, dan tanpa media lekatprosentase $50 \%$ dari limbah asli

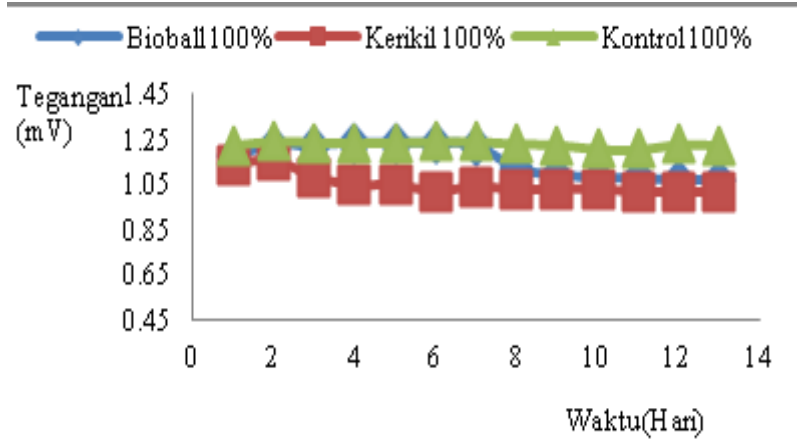

Gambar 6. Kurva Tegangan ( $\mathrm{mV}$ ) dengan media lekat bioball, kerikil, dan tanpa media lekatprosentase $100 \%$ dari limbah asli

\section{Energi dan daya listrik pada variasi media lekat}

Berdasarkan persamaan (1) tampak bahwa daya $(P)$ sangat dipengaruhi kuat arus (I) dan tegangan (V) yang dihasilkan. Pada penelitian ini arus listrik yang dihasilkan pada variasi media lekat cenderung stabil. Disisi lain tegangan listrik cenderung mengalami penurunan. Sehingga daya yang dihasilkan cenderung mengalami penurunan.Perbedaan media lekat menghasilkan daya listrik yang signifikan $(\alpha<0,05)$ baik pada media lekat kerikil, bioball maupun tanpa media lekat. Energi listrik merupakan perkalian antara daya $(P)$ dan waktu (t). Berdasarkan hasil penelitian menunjukkan bahwa adanya media lekat berpengaruh signifikan terhadap energi listrik yang dihasilkan. Hal ini ditunjukkan dari nilai signifikansi sebesar 0,017 . Energi listrik tertinggi sebesar 179,54 $\mathrm{mWh}$ yang dihasilkan oleh substrat dengan penambahkan media lekat kerikil. Pada media lekat kerikil dihasilkan penurunan energi yang tajam pada hari ke-4 sampai ke-6. Apabila melihat tegangan listrik pada hari ke-4 dan ke-6, adanya media lekat kerikil menyebabkan penurunan tegangan yang lebih besar dibandingkan dengan variasi lainya. Oleh karena itu, energi yang dihasilkan juga semakin menurun.

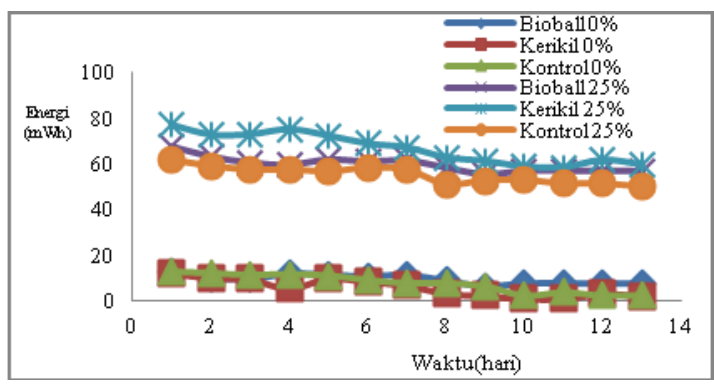

Gambar 7.Energi listrik yang dihasilkan pada variasi media lekat dengan konsentrasi limbah cair industri tahu $0 \%$ dan $25 \%$ 


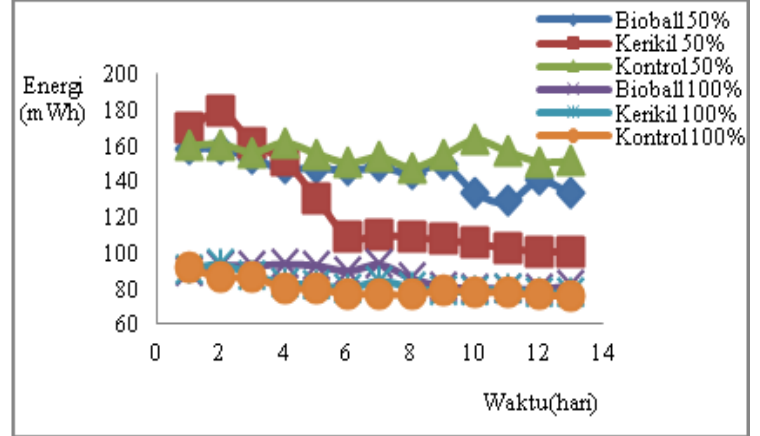

Gambar 8. Energi listrik yang dihasilkan pada variasi media lekat dengan konsentrasi limbah cair industri tahu $50 \%$ dan $100 \%$

\section{Efisiensi penyisihan konsentrasi COD pada reaktor MFCs}

Adanya variasi konsentrasi menunjukkan perbedaan bilangan signifikan dibandingkan tanpa media lekat. Signifikansi yang diperoleh (sig.) sebesar 0,000. Menurut Borja dkk (2012), semakin besar konsentrasi COD pada influen akan semakin kecil efisiensi penyisihan yang terjadi. Hasil penelitian menunjukkan bahwa penurunan COD maksimum terjadi pada konsentrasi rendah. Hal ini disebabkan oleh semakin tinggi konsentrasi COD dalam umpan (influen), semakin besar jumlah substrat yang terkandung dalam limbah cair, dengan demikian beban organik yang harus diuraikan oleh mikroba juga semakin besar. Pada penelitian lain disebutkan tingkat efisiensi penyisihan COD menurun bila tingkat pembebanan hidrolik dan organik meningkat (Aslan dan Nusret, 2008). Hal ini diduga karena semakin terbatasnya jumlah mikroorganisme pengurai aktif, dengan demikian kemampuan mendegradasi substrat pun semakin terbatas. Menurut Gerardi (2006), karena kuantitas limbah organik yang relatif besar yang terdapat pada proses pengolahan anaerobik, aktivitas bakteri dan faktor operasional yang mempengaruhi aktivitas bakteri sangat kritis.

Nachaiyasit (1997) menyatakan bahwa tingginya konsentrasi dalam reaktor cenderung meningkatkan kestabilan limbah sehingga efisiensi penyisihan kadar COD menurun. Pada $\mathrm{pH}$ rendah dan konsentrasi tinggi, populasi mikroba lebih memilih menghasilkan produk utama mereka seperti asetat dan butirat dari pada format dan propoinat. Hal ini juga meningkatkan stabilitas penyisihan dan meningkatkan jumlah gas metana $\left(\mathrm{CH}_{4}\right)$.

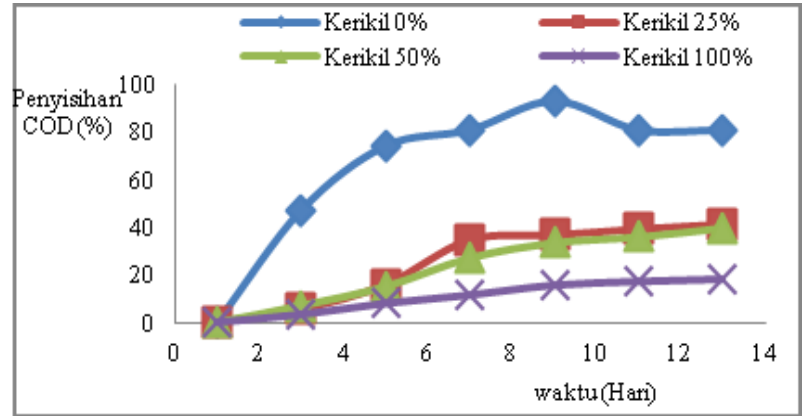

Gambar 9. Prosentase penurunan kadar COD pada variasi konsentrasi limbah dengan media lekat kerikil

\section{Arus listrik pada variasi Konsentrasi COD}

Variasi komposisi prosentase konsentrasi COD $25 \%$ menghasilkan arus tertinggi sebesar $4,48 \mu \mathrm{A}$. Variasi $50 \%$ menghasilkan arus sebesar $7,25 \mu \mathrm{A}$ dan Variasi $100 \%$ menghasilkan arus 3,29 $\mu \mathrm{A}$. Variasi konsentrasi $50 \%$ limbah cair industri tahu menghasilkan arus paling tinggi diantara variasi lainnya.

Tingginya arus listrik mengindikasikan bahwa elektron yang dialirkan menuju katoda lebih besar dari yang lainnya. Apabila menilik jumlah konsentrasi COD yang terdegradasi sebesar $491,3 \mathrm{mg} / \mathrm{l}$ pada variasi limbah $50 \%$. Ada kemungkinan potensi konsentrasi COD awal yang di ubah menjadi arus lebih banyak. Menurut Haslett(2012), semakin banyak konsentrasi bahan organik maka potensi menghasilkan arus listrik semakin besar arus listrik. Dalam penelitian diperoleh hasil yang sebaliknya yaitu pada variasi $100 \%$. Kosentrasi COD dengan variasi $100 \%$ menghasilkan arus yang lebih kecil dari $50 \%$. Hal ini kemungkinan penghambat elektron pada variasi $100 \%$ lebih banyak dibandingkan dengan konsentrasi $50 \%$. Fenomena ini kemungkinan timbul karena selama proses pengolahan terdapat akseptor elektron yang menghambat transfer elektron menuju ke anoda.

Selain pengaruh terbentunya biofilm di permukaan elektroda anoda dan proses fermentasi, pada variasi konsentrasi $100 \%$ dihasilkan substrat kompartemen anoda berwarna hitam ketika penelitian. Kemungkinan warna ini akibat terjadi reduksi sulfat $\left(\mathrm{SO}_{4}{ }^{2-}\right)$ menjadi sel bakteri, karbondioksida, air, sulfida, dan senyawa organik rantai pendek seperti asam dan alkohol sesuai dengan persamaan reaksi berikut:

$2 \mathrm{CH}_{3} \mathrm{CHOHCOOH}+\mathrm{SO}_{4}{ }^{2-}+\mathrm{H}^{+} \rightarrow 2 \mathrm{CH}_{3} \mathrm{COO}^{-}+2 \mathrm{CO}_{2}+2 \mathrm{H}_{2} \mathrm{O}+\mathrm{HS}$

Menurut Gerardi(2006), senyawa $\mathrm{SO}_{4}{ }^{2-}$ berperan sebagai akseptor elektron pada proses reduksi sulfat dan degradasi substrat. Jadi kemungkinan efek yang ditimbulkan dari proses 
ini berperan dalam penurunan arus listrik. Senyawa sulfat berasal dari degradasi limbah awal.

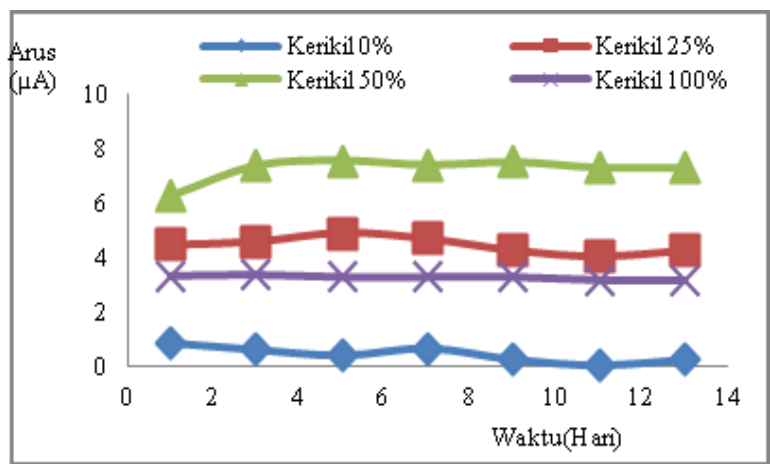

Gambar 10. Kurva arus listrik yang dihasilkan pada variasi konsentrasi dengan media lekat kerikil

\section{Tegangan listrik pada variasi Konsentrasi} COD

Selama periode penelitian dalam sistem batch, tegangan yang dihasilkan semakin hari semakin menurun. Hal ini karena pengaruh proses biokimia yang terjadi selama pengolahan. Nachaiyasit (1997) menyatakan bahwa tingginya konsentrasi dalam reaktor cenderung meningkatkan kestabilan limbah sehingga efisiensi penyisihan kadar COD menurun. Salah satu yang berperan penting terhadap perubahan tegangan adalah nilai $\mathrm{pH}$. Salah satu pengaruh pengolahan secara anaerob dalam reaktor MFCs adalah naiknya nilai $\mathrm{pH}$. Kemungkinan penurunan tegangan akibat adanya kenaikan nilai $\mathrm{pH}$ baik pada variasi konsentrasi $25 \%, 50 \%$ maupun $100 \%$. Nilai tegangan yang terukur semakin menurun akibat kenaikan $\mathrm{pH}$. Hal ini sesuai dengan penyataan Logan(2007) bahwa semakin tinggi $\mathrm{pH}$ larutan, maka tegangan yang terukur dalam reaktor MFCs semakin rendah.

Daya listrik $(P)$ dipengaruhi kuat arus (I) dan tegangan (V) yang dihasilkan. Pada penelitian ini arus listrik yang dihasilkan pada variasi konsentrasi cenderung stabil. Disisi lain tegangan listrik cenderung mengalami penurunan akibat kenaikan nilai $\mathrm{pH}$ substrat sehingga daya yang dihasilkan cenderung mengalami penurunan. Daya listrik yang dihasilkan pada variasi konsentrasi $0 \%$ tertinggi sebesar 0,55 $\mathrm{mW}$; konsentrasi $25 \%$ sebesar $3,21 \mathrm{~mW}$; konsentrasi $50 \%$ sebesar $7,06 \mathrm{~mW}$. Variasi konsentrasi $100 \%$ menghasilkan daya sebesar $3,95 \mathrm{~mW}$. Nilai ini lebih kecil dari pada variasi konsentrasi $50 \%$. Hal ini kemungkinan karena pada variasi $100 \%$ limbah cair tahu timbul senyawa sulfida yang menghambat tranfer elektron menuju anoda yang ditandai perubahan warna limbah cair menjadi hitam dan menyebabkan arusnya rendah. Padahal daya merupakan perkalian antara arus listrik dan tegangan. Sehingga semakin rendah arus listrik maka daya listriknya semakin rendah. Perbedaan konsentrasi menghasilkan daya listrik yang signifikan $(\alpha<0,05)$ baik pada variasi $0 \%, 25 \%$, $50 \%$ maupun $100 \%$. Berdasarkan hasil uji Multiple Comparisons, variasi konsentrasi menunjukkan perbedaan signifikan yang di tunjukkan dari nilai signifikansi sebesar 0,0000. Nilai ini lebih kecil dari taraf signifikansi sebesar 0,05 .

\section{Energi dan daya listrik pada variasi Konsentrasi COD}

Energi listrik merupakan perkalian antara daya (P) dan waktu (t). Berdasarkan hasil penelitian menunjukkan bahwa variasi konsentrasi berpengaruh terhadap energi listrik yang dihasilkan, baik komposisi $0 \%, 25 \%, 50 \%$, dan $100 \%$. Hal ini ditunjukkan dari nilai signifikansi sebesar 0,000 . Energi listrik tertinggi dihasilkan oleh variasi konsentrasi limbah cair industri tahu $50 \%$ dengan media lekat kerikil sebesar 179,54 mWh. Hal ini sebanding dengan daya listrik yang dihasilkan. Gambar 11 berikut merupakan grafik energi yang dihasilkan selama 13 hari penelitian.

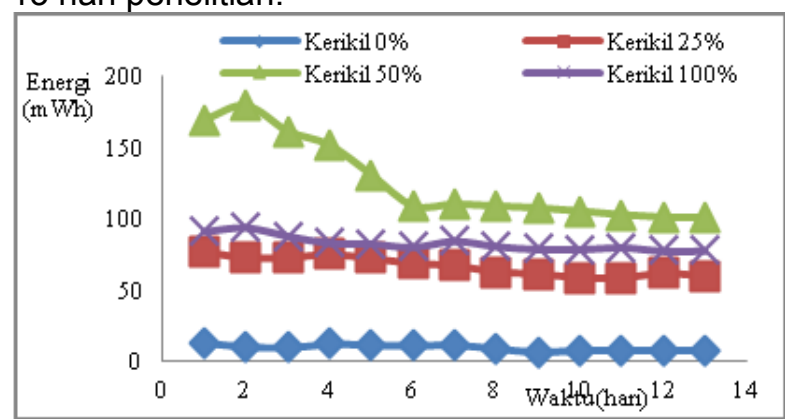

Gambar 11. Energi listrik yang dihasilkan pada variasi konsentrasi dengan media lekat kerikil

\section{KESIMPULAN}

Berdasarkan hasil penelitian dan pembahasan yang telah dilakukan, dapat diambil beberapa kesimpulan sebagai berikut:

1. Adanya media lekat (attached growth media) pada reaktor MFCs mengakibatkan kenaikan prosentase penyisihan COD limbah cair industri tahu.

2. Energi listrik yang dihasilkan pada media lekat kerikil dengan variasi konsentrasi $50 \%$ sebesar 179,54 mWh dan media lekat bioball sebesar 158,30 mWh pada hari ke-1 dan ke2. Sedangkan limbah tanpa media lekat menghasilkan daya listrik tertinggi sebesar 163,03 mWh pada hari ke-11.

3. Efisiensi penyisihan COD semakin rendah akibat bertambahnya konsentrasi COD awal. 
4. Energi listrik yang dihasilkan pada variasi konsentrasi $0 \%$ tertinggi sebesar $13,04 \mathrm{mWh}$; konsentrasi $25 \%$ sebesar $77,03 \mathrm{mWh}$; konsentrasi $50 \%$ sebesar 179,54 mWh. Variasi konsentrasi 100\% menghasilkan daya sebesar 94,11 $\mathrm{mWh}$. Energi listrik pada variasi konsentrasi $100 \%$ lebih kecil dari pada variasi konsentrasi $50 \%$. Hal ini terjadi karena timbul senyawa sulfida yang menghambat transfer elektron menuju anoda yang ditandai perubahan warna limbah cair menjadi hitam yang berakibat rendahnya arus listrik.

5. Efisiensi Coulombic $(\varepsilon \mathrm{C})$ maksimum mencapai $\quad 0,016 \%$. Rendahnya $\varepsilon \mathrm{C}$ kemungkinan karena adanya produk-produk fermentasi dan biofilm pada elektroda anoda yang menghambat transfer elektron menuju elektroda anoda.

\section{SARAN}

Saran yang dapat digunakan dalam penelitian selanjutnya adalah sebegai berikut:

1. Penelitian lebih lanjut dengan menggunakan media lekat kerikil dan konsentrasi substrat limbah tahu sebesar $50 \%$ dari limbah awal agar diperoleh daya listrik yang maksimum.

2. Perlu menambahkan waktu penelitian agar semua produk fermentasi dapat teroksidasi secara sempurna menjadi gas.

3. Pengujian komposisi hasil proses fermentasi pada waktu tertentu perlu dilakukan menggunakan Gas Chromatography untuk memastikan jumlah dan jenis produk fermentasi apa yang terbentuk

4. Pemilihanan elektroda anti bakteri yang memungkinkan biofilm tidak melekat tetapi bersifat konduktor.

\section{DAFTAR PUSTAKA}

Alaerts, G dan Santika, S S. 1984. Metode Penelitian Air. Usaha Nasional. Surabaya.

Aslan, Sibel dan Nusret, S,. 2008. The Performance of UASB Reactors Treating

Journal of High- Strength Wastewaters.

Environmental Health. National Environmental Health Association.

Bard, A. J.; Parsons, R.; Jordan, J., Eds. Standard Potentials in Aqueous Solution; Marcel Dekker: New York, 1985.

Borja, G. M., Eugenio M. M., Guillermo G., Octavio 2012. Engineering Escherichia Coli to increase plasmid DNA production in high cell-density cultivations in batch mode. Microbial Cell Factories 11:132

Franks, Ashley E. and Nevin, Kelly P. 2010. Department of Microbiology, University of Massachusetts, Amherst, USA.

Gerardi, Michael H. 2006. Wastewater Bacteria. A John Wiley \& Sons, Inc., Publication

Guerrero-Rangel, N., J.A. Rodríguez-de la Garza,Y. Garza-García, L.J. RíosGonzález, G.J. Sosa Santillán, I.M. De la Garza-Rodríguez. 2010. Comparative study of three cathodic electron acceptors on the performance of mediatorless microbial fuel cell. Int. J. Electric. Power Eng., 4(1): 27-31

Habermann. W dan Pommer, EH. 1991. Biological fuel cells with sulphide storage capacity. Appl Microbiol Biotechnol;35:128-33.

Haslett, N.D. 2012. Development of a Eukaryotic Microbial Fuel Cell Using Arxula Adeninivorans. Thesis Submitted in partial fulfillment of the requirements for the doctorate of philosophy of biochemistry. Licoln University.

Kaswinarni, F. 2007. Kajian Teknis Pengolahan Limbah Padat dan Cair Industri Tahu. Sekolah Pascasarjana: Universitas Sumatera Utara.

Kawai, K., Urano, M., Ebisu, S., 2000. Effect of surface roughness of porcelain on adhesion of bacteria and their synthesizing glucans. J. Prosthet. Dent. 83, 664- 667.

Kim, B.H, Chang I.S, Gil, G.C, Park H.S, Kim H.J. 2003. Novel BOD sensor using mediatorless microbial fuel cell. Biotechnol. Lett. 25: 541-545.

Lee, Parameswaran,P., Kato M., A., Torres, C.I., Rittmann, B.E. 2008. Evaluation of energy-conversion efficiencies in microbial fuel cells (MFCs) utilizing fermentable and non-fermentable substrates. Water Res, 42(6-7), 1501-1510.

Li B, Karl Scheible, Micheal Curtis. 2011. Electricity Generation From Anaerobic Wastewater Treatment In Microbial Fuel Cells. Water Environment Research Foundation. Now York State Energi Research And Development Authority.

Liu et al,2004 dalam Zhou, Minghua et al. 2011. An Overview Of Electrode Materials In Microbial Fuel Cells. Journal Of Power Sources. 196 (2011) 4427-4435

Liu, H., Ramnarayanan R. dan Logan, B. E. 2004. Production of electricity during wastewater treatment using a 
single chamber microbial fuel cell. Environ. Sci. Technol. vol. 38(7): pp.2281-2285.

Liu dkk, 2008 dalam Kristin E.2012. Produksi Energi Listrik Melalui Microbial Fuel Cell Menggunakan Limbah Industri Tempe. Skripsi. Program Studi Teknologi Bioproses.Fakultas Teknik. Universitas Indonesia

Logan, B.E. 2005. Simultaneous Wastewater Treatment and Biological Electricity Generation. Water Science \& Technology Vol 52 No 1-2 pp 31-37 CIWA Publishing

Logan, B.E.2007. Microbial Fuel Cells.WileyInterscience. ISBN 978-0-470-23948

Lovley, D.R. 2008. The microbe electric: conversion of organic matter toelectricity. Current Opinion in Biotechnology. Vol. 19:pp 1-8. USA.

Madigan, M. T., John M. Martinko, David A. Stahl, David P. Clark. 2011. Brock Biology of Microorganisms Thirteenth Edition. BenjaMin CumMings: the United States of America

Metcalfand Eddy, 1991. Wastewater Engineering 4rdedition,Mc-Graw Hill

Min, 2005 dalam Zhang, Y. 2012. Energy Recovery From Waste Streams With Microbial Fuel Cell (MFC)-Based Technologies. Thesis. Departement of Environment Engineering. Technical University of Denmark.

Min, B., dan Logan, B.E. 2004. Continuous electricity generation from domestic wastewater and organic substrates in a flat plate microbial fuel cell. Environ

Sci Technol, 38(21), 5809- 5814.

Nachaiyasit, S. and D.C. Stuckey, 1997. The effect of shock loads on an anaerobic baffled reactor (ABR), 1. Step changes in feed concentration at constant retention time. Water Research, 31(11): 2737-3747

Quirynen, M., dan Bollen, C.M., 1995. The influence of surface roughness and surfacefree energy on supra- and subgingival plaque formation in Man A review of the literature. J. Clin. Periodontol. 22, 1-14.

Rabaey, K. dan Verstraete W. 2005. Microbial fuel cells: novel biotechnology for energy generation. Trends Biotechnol; 6: 291-298.

Sani, Elly Yuniarti.2006. Pengolahan air limbah tahu menggunakan Reaktor anaerob bersekat dan aerob. Thesis Program

Magister IImu Lingkungan Program Pascasarjana Universitas Diponegoro. Semarang

Said, N. I., dan Wahjono, H. D., 1999. Teknologi Pengolahan Limbah Tahu-

Tempe Dengan Proses Biofilter Anaerob dan Aerob, BPPT, Jakarta.

Tang, H., Cao, T., Wang, A., Liang, X., Salley, S.O., McAllister, J.P., Simon, Ng.K.Y., 2007. Effect of surface modification of silicone on Staphylococcus epidermidis adhesion and colonization. J. Biomed.

Mater. Res. Part A. 80A, 885-894.

Wagiman dan Suryandono, 2006. A Tofu Wastewater Treatment With A Combination of Anaerobic Baffled Reactor and Activated Sludge system,

Majalah Ilmu dan Teknologi Pertanian, XVI.

Widarti, B.N., Siti Syamsiah, dan Panut Mulyono. 2012. Degradasi Substrat Volatile Solid pada Produksi Biogas dari Limbah Pembuatan Tahu dan Kotoran Sapi. Jurnal Rekayasa Proses, Vol. 6, No. 1. Universitas Gadjah Mada: Yogyakarta.

Wijeyekoon S., Mino T., Satoh H. and Matsuo T. 2004. Effects of substrate loading rate on biofilm structure, Water Research, Vol. 38, pp. 2479-2488.

Zhang, Y. 2012. Energy Recovery From Waste Streams With Microbial Fuel Cell (MFC)-

Based Technologies. Thesis. Departement of Environment Engineering. Technical University of Denmark. 